\title{
Pengaruh sistem tanam dan pupuk organik terhadap karakter agronomi turi dan rumput benggala pada tanah salin
}

\section{(Effect of cropping system and organic fertilizer on agronomic characteristic of Sesbania grandiflora and Panicum maximum at saline soil)}

\author{
R. Tolib, F. Kusmiyati, dan D. R. Lukiwati \\ Agrioecotechnology, Faculty of Animal and Agricultural Sciences, Diponegoro University \\ Tembalang Campus, Semarang 50275 - Indonesia \\ Corresponding E-mail: rokhimunt@gmail.com
}

\begin{abstract}
The research was conducted to evaluate the effect of cropping system and organic fertilizer on agronomic characteristic of $S$. Grandiflora and P. maximum at saline soil. Organic fertilizer used cow manure. Saline soil Electrical conductivity was $4.10 \mathrm{dS} / \mathrm{m}$. The research used complete block design with 9 treatments and 3 replicatios. The treatments were : S. grandiflora monoculture without manure (M1); $S$. grandiflora +10 ton manure/ha (M2); S. grandiflora +20 ton manure/ha (M3); mixed cropping of $P$. maximum and $S$. Grandiflora without manure (M4), mixed cropping of $S$. Grandiflora and P. maximum +10 ton manure/ha (M5); mixed cropping of $S$. Grandiflora and P. maximum +20 ton/ha (M6); P. maximum monoculture without manure (M7); P. maximum monoculture +10 ton manure/ha (M8); $P$. maximum monoculture +20 ton manure/ha (M9). The application of manure at 10 ton/ha increased the number of leaf, a-chlorophyll, total-chlorophyll, and dry matter production of $S$. grandiflora and $P$. maximum at saline soil. Mixed cropping increased the efficiency of land use.
\end{abstract}

Keywords : Agronomic, cropping system, organic, S. grandiflora, P. maximum.

\begin{abstract}
ABSTRAK
Penelitian bertujuan untuk mengkaji pengaruh sistem tanam serta dosis pupuk kandang terhadap karakter agronomi turi dan rumput benggala pada tanah salin. Salinitas tanah yang digunakan termasuk sedang, dengan daya hantar listrik 4,10 dS/m. Pupuk kandang (pukan) yang digunakan berasal dari ternak sapi. Rancangan percobaan yang digunakan, rancangan acak kelompok monofaktor terdiri dari 9 perlakuan dengan 3 kali ulangan, yaitu monokultur turi tanpa pukan (M1); monokultur turi +10 ton pukan/ha (M2); monokultur turi +20 ton pukan/ha (M3); tumpangsari turi dan rumput benggala +0 ton pukan/ha (M4); tumpangsari turi dan rumput benggala + 10 ton pukan/ha (M5); tumpangsari turi dan rumput benggala +20 ton pukan/ha (M6); monokultur rumput benggala tanpa pukan (M7); monokultur rumput benggala +10 ton pukan/ha (M8); monokultur rumput benggala +20 ton pukan/ha (M9). Hasil penelitian menunjukkan bahwa aplikasi pupuk kandang dengan dosis 10 ton/ha mampu meningkatkan jumlah daun, kadar klorofil a, kadar klorofil total, serta produksi bahan kering turi dan rumput benggala pada tanah salin. Sistem tanam tumpangsari mampu meningkatkan efisiensi penggunaan lahan.
\end{abstract}

Kata kunci : Agronomi, sistem tanam, organik, turi, rumput benggala.

\section{PENDAHULUAN}

Upaya perluasan lahan pertanian kini mengarah pada pemanfaatan lahan marjinal, seperti tanah salin. Luas tanah salin semakin meningkat seiring kenaikan suhu dan permukaan air laut akibat perubahan iklim dan pemanasan global. Indonesia merupakan negara kepulauan dengan kawasan pesisir yang luas pada tiap wilayah pulaunya. Luas tanah salin di Indonesia sekitar 0,44 juta ha (BBPPSL, 2006). Potensi sumber daya kawasan pesisir dapat ditingkatkan 
melalui pemanfaatan tanah salin untuk pengembangan budidaya tanaman pakan. Turi dan rumput benggala termasuk tanaman pakan yang toleran salinitas (Fuskhah et al., 2014 dan Kusmiyati et al., 2016).

Tanah salin terbentuk dari akumulasi garam garam, terutama $\mathrm{NaCl}, \mathrm{Na}_{2} \mathrm{SO}_{4}, \mathrm{CaCO}_{3}$, dan $\mathrm{MgCO}_{3}$. Tanah salin dapat terjadi akibat pengaruh intrusi air laut, aliran lumpur dari laut, irigasi air asin, pelapukan (mineral, batuan, dan fosil bergaram), residu pupuk kimia berlebih, residu pertambangan minyak dan gas, serta laju evaporasi tinggi yang menyebabkan garam garam tertinggal dalam tanah dan tidak tercuci sempurna (Tan, 1991). Tingkat salinitas tanah dibedakan menjadi non salin (DHL $=0-2 \mathrm{dS} / \mathrm{m})$, rendah $(\mathrm{DHL}=2-4 \mathrm{dS} / \mathrm{m})$, sedang $(\mathrm{DHL}=4-8$ $\mathrm{dS} / \mathrm{m})$, tinggi $(\mathrm{DHL}=8-16 \mathrm{dS} / \mathrm{m})$, dan sangat tinggi (DHL $=>16 \mathrm{dS} / \mathrm{m})$ (Abrol et al., 1988).

Tanah salin memiliki pH cukup tinggi, antara 7 - 8,5. Cekaman salinitas akibat berlebihnya ion $\mathrm{Na}^{+}$membuat partikel tanah tersuspensi secara tetap sehingga permeabilitas tanah terhambat dan tekanan osmosis tanaman meningkat (Tan, 1991). Cekaman salinitas mengakibatkan plasmolisis, yaitu keluarnya $\mathrm{H}_{2} \mathrm{O}$ dari sel tanaman. Plasmolisis menyebabkan akar terhambat dalam menyerap air dan unsur hara sehingga memicu matinya sel dan jaringan tanaman (Sutedjo, 1995). Perubahan struktur tanaman akibat salinitas antara lain jumlah daun semakin sedikit dengan ukuran lebih kecil, penebalan kutikula dan lapisan lilin permukaan daun, serta lignifikasi akar lebih awal (Harjadi dan Yahya, 1988). Upaya mengurangi dampak cekaman salinitas dapat dilakukan melalui pemberian pupuk kandang.

Pupuk kandang mampu meningkatkan kapasitas tukar kation (KTK) tanah salin. Kation kation penyebab toksisitas seperti $\mathrm{Na}, \mathrm{Cl}, \mathrm{Al}, \mathrm{Fe}$, $\mathrm{Br}$, dan $\mathrm{Ca}$ dapat diminimalisir, karena kompetisi antar ion positif dan ion negatif berada pada kompleks jerapan partikel koloid bahan organik pupuk kandang (Cha-um et al., 2011). Sutedjo (1995) menyatakan bahwa bahan organik yang terdapat dalam pupuk kandang mampu menggemburkan lapisan permukaan tanah (top soil), menetralkan $\mathrm{pH}$, meningkatkan aktivitas mikroorganisme tanah, meningkatkan daya menahan air serta kesuburan tanah.

Nilai nisbah kesetaraan lahan (NKL) hingga lebih dari 1 menunjukkan produktivitas dan penggunaan lahan pada sistem tanam tumpangsari lebih efisien dibanding sistem tanam monokultur (Mahapatra, 2016). Turi termasuk leguminosa bersimbiosis mutualisme dengan bakteri Rhizobium sp. dan membentuk nodul di perakarannya untuk memfiksasi nitrogen bebas dari udara sehingga mampu menjadikan unsur $\mathrm{N}$ tersedia (Susilawati et al., 2011). Penerapan sistem tanam tumpangsari diharapkan mampu meningkatkan ketersediaan $\mathrm{N}$ hasil fiksasi dari turi untuk rumput benggala.

Penelitian ini bertujuan untuk mengkaji pengaruh sistem tanam serta dosis pupuk kandang terhadap karakter agronomi turi dan rumput benggala pada tanah salin.

\section{MATERI DAN METODE}

Penelitian telah dilaksanakan pada bulan Juli - November 2016 di lahan salin di Desa Dresi Wetan, Kecamatan Kaliori, Rembang, Jawa Tengah. Analisis tanah dan pupuk kandang dilakukan di Balai Pengkajian Teknologi Pertanian Jawa Tengah. Analisis bahan kering, kadar klorofil a, klorofil b, dan klorofil total dilaksanakan di Laboratorium Ekologi dan Produksi Tanaman, Fakultas Peternakan dan Pertanian, Universitas Diponegoro, Semarang.

Percobaan disusun berdasarkan rancangan acak kelompok monofaktor, terdiri dari 9 perlakuan dengan 3 kali ulangan sebagai kelompok, yaitu monokultur turi tanpa pukan (M1); monokultur turi +10 ton pukan/ha (M2); monokultur turi+ 20 ton pukan /ha (M3); tumpangsari turi dan rumput benggala +0 ton pukan/ha (M4); tumpangsari turi dan rumput benggala +10 ton pukan /ha (M5); tumpangsari turi dan rumput benggala +20 ton pukan/ha (M6); monokultur rumput benggala tanpa pukan (M7); monokultur rumput benggala +10 ton pukan/ha (M8); monokultur rumput benggala +20 ton pukan/ha (M9).

Pengolahan tanah dilakukan 2 minggu sebelum penanaman, meliputi pembersihan, penanaman, dan penggaruan tanah. Luas total lahan yang digunakan $\pm 1.344 \mathrm{~m}^{2}$, masing - masing petak berukuran $6 \mathrm{~m} \times 7 \mathrm{~m}$, dengan total 27 petak. Pupuk kandang diberikan pada 2 minggu sebelum tanam atau pada saat setelah pengolahan tanah, dengan dosis 0 ton/ha, 10 ton/ha, dan 20 ton/ha, sesuai perlakuan. Pupuk dasar juga diberikan pada 
saat tanam, yaitu pupuk urea, SP36, dan $\mathrm{KCl}$, masing - masing dengan dosis $60 \mathrm{Kg} \mathrm{N} / \mathrm{ha} ; 100$ $\mathrm{Kg} \mathrm{P}_{2} \mathrm{O}_{5} /$ ha; dan $100 \mathrm{Kg} \mathrm{K}_{2} \mathrm{O} / \mathrm{ha}$.

Bahan tanam yang digunakan adalah benih turi (biji), bibit rumput benggala (sobekan rumpun/pols). Benih turi ditanam dengan sistem tugal, dengan kedalaman lubang tanam $5 \mathrm{~cm}$. Jumlah benih untuk setiap lubang adalah 3 biji, dan pada 1 minggu setelah tanam, hanya disisakan 1 bibit vigor yang dibiarkan tumbuh. Dua sobekan/pols rumput benggala ditanam pada tiap lubang tanam dengan kedalaman $10-15 \mathrm{~cm}$. Jarak tanam yang digunakan $100 \mathrm{~cm} \times 75 \mathrm{~cm}$, pada sistem tanam tumpangsari, turi ditanam diantara lajur baris rumput benggala.

Rumput benggala dipotong dan disisakan 10 $\mathrm{cm}$ batang rumput diatas permukaan tanah, sedangkan turi dipotong pada tiap anak cabang dengan mengambil batang yang masih muda. Potong paksa rumput benggala dilakukan pada 4 minggu setelah tanam, untuk penyeragaman tanaman. Defoliasi ke-1 rumput benggala dilakukan pada 6 minggu setelah potong paksa, sedangkan defoliasi ke-2 dilakukan pada 4 minggu setelah defoliasi ke-1. Defoliasi turi baru dilakukan pada 14 minggu setelah tanam, atau bersamaan dengan defoliasi ke-2 pada rumput benggala.

Karakter agronomi yang diamati meliputi jumlah daun, kadar klorofil (klorofil a, klorofil b, dan klorofil total), dan produksi bahan kering. Pengamatan dilakukan pada 5 sampel tanaman turi dan 5 sampel tanama rumput benggala pada tiap petak. Jumlah daun diamati setiap 2 minggu sekali. Kadar klorofil (klorofil a, klorofil b, dan klorofil total), produksi bahan kering diamati pada setiap defoliasi. Pengukuran kadar klorofil daun dilakukan menggunakan metode spektofotometri dengan petunjuk Prawiranata et al. (1981). Bahan kering dihitung berdasarkan petunjuk Salim et al. (2016). Nisbah kesetaraan lahan dihitung berdasarkan petunjuk Mahapatra (2011). Data yang diolah hanya data yang diamati pada defoliasi ke-2. Data yang diperoleh diuji dengan analisis ragam (Uji $\mathrm{F}$ ) pada taraf $5 \%$, apabila berpengaruh nyata $(p<0,05)$, maka dilanjutkan dengan Uji Jarak Ganda Duncan (UJGD) untuk mengetahui perbedaan antar perlakuan.

\section{HASIL DAN PEMBAHASAN}

Analisis tanah menunjukkan bahwa tanah yang digunakan sebagai media tanam termasuk tanah alluvial dengan tekstur liat lempung berpasir, $\mathrm{pH}$ 7,72 (alkalis) dan DHL 4,10. Berdasarkan klasifikasi Abrol et al. (1998), salinitas tanah tersebut termasuk sedang.

\section{Jumlah Daun}

Hasil UJGD (Tabel 1), menunjukkan bahwa jumlah daun turi dan rumput benggala tanpa pukan, nyata lebih rendah $(\mathrm{p}<0,05)$ dibanding dengan pukan. Jumlah daun turi dan rumput benggala dengan dosis 10 ton pukan/ha tidak

Tabel 1. Jumlah daun turi dan rumput benggala pada tanah salin dengan sistem tanam dan dosis pukan yang berbeda

\begin{tabular}{lcc}
\hline \hline \multicolumn{1}{c}{ Perlakuan } & Turi & Rumput \\
\hline & ------- helai------- \\
M1 (Turi) & $48,80^{\mathrm{c}}$ & - \\
M2 (Turi + 10 ton pukan/ha) & $139,81^{\mathrm{ab}}$ & - \\
M3 (Turi + 20 ton pukan/ha) & $150,53^{\mathrm{a}}$ & - \\
M4 (Tumpangsari) & $66,66^{\mathrm{bc}}$ & $88,13^{\mathrm{b}}$ \\
M5 (Tumpangsari + 10 ton pukan/ha) & $176,33^{\mathrm{a}}$ & $237,86^{\mathrm{b}}$ \\
M6 (Tumpangsari + 20 ton pukan/ha) & $146,20^{\mathrm{ab}}$ & $244,20^{\mathrm{a}}$ \\
M7 (Rumput Benggala) & - & $127,86^{\mathrm{b}}$ \\
M8 (Rumput Benggala + 10 ton pukan/ha) & - & $242,08^{\mathrm{a}}$ \\
M9 (Rumput Benggala + 20 ton pukan/ha) & - & $229,80^{\mathrm{b}}$ \\
\hline Sup
\end{tabular}

Superskrip berbeda pada kolom yang sama menunjukkan perbedaan nyata $(\mathrm{p}<0,05)$. 
berbeda nyata terhadap dosis 20 ton pukan/ha. Jumlah daun turi dan rumput benggala dengan sistem tanam tumpangsari tidak berbeda nyata terhadap sistem tanam monokultur.

Kadar $\mathrm{N}$ tanah salin pada penelitian ini termasuk rendah, hanya $0,13 \%$. Pupuk kandang yang digunakan pada penelitian kali ini, mempunyai kadar $\mathrm{N} 1,65 \%$, berarti dalam dosis 10 ton/ha setara dengan $165 \mathrm{~kg} \mathrm{~N} / \mathrm{ha}$, ditambah suplai $\mathrm{N}$ dari pupuk urea yang diberikan. Kadar $\mathrm{N}$ dalam pupuk urea mencapai $46 \%$, berarti dalam dosis $60 \mathrm{~kg} \mathrm{~N} / \mathrm{ha}$ setara dengan $130 \mathrm{~kg} \mathrm{~N} / \mathrm{ha}$, sehingga kebutuhan $\mathrm{N}$ rumput maupun legume masih tercukupi. Unsur $\mathrm{N}$ merupakan salah satu unsur yang berperan dalam pembentukan daun. Menurut Hidayat dan Suwarno (2012), unsur N berfungsi membentuk klorofil dan protein sebagai senyawa pembangun sel dan jaringan daun tanaman. Peningkatan hasil fotosintat akan memacu hormon pertumbuhan membentuk tunas tunas daun. Purbajanti et al. (2010), menyebutkan bahwa pemberian pupuk kandang dengan kandungan $\mathrm{N}$ total mencapai 1,67\% mampu meningkatkan ketersediaan $\mathrm{N}$ pada tanah salin.

Pemberian pukan mampu menurunkan salinitas, serta memperbaiki sifat biologi tanah salin dengan meningkatkan aktivitas mikroorganisme penyubur tanah. Pemberian pukan dengan kadar C - organik 30,64\% diharapkan mampu meningkatkan ketersediaan C organik tanah pada penelitian ini, yang semula hanya $1,08 \%$. Legume turi mampu bersimbiosis dengan bakteri rhizobium untuk memfiksasi $\mathrm{N}$. Namun, Dhanapackiam dan Ilyas (2013), aktivitas mikroorganisme melalui simbiosis antara rhizobium dan turi dapat terhambat akibat cekaman salinitas pada konsentrasi $50 \mathrm{mM} \mathrm{NaCl}$, ditandai dengan penurunan jumlah bintil hingga $62 \%$ dibanding kondisi normal. Menurut Yuliprianto (2010), alternatif untuk meningkatkan aktivitas mikroorganisme tanah, dapat dilakukan melalui pemberian pukan, karena bahan organik yang terdapat dalam pukan mampu menyediakan sumber energi (karbon) bagi mikroorganisme penyubur tanah.

Salinitas tanah pada penelitian ini termasuk sedang, dengan DHL 4,10 dS/m. Akibatnya, efek pemupukan dengan dosis 10 ton pukan/ha tidak berbeda nyata terhadap dosis 20 ton pukan/ha. Hal ini dikarenakan dosis 10 ton pukan/ha sudah mampu menurunkan DHL, selain itu turi dan rumput benggala masih tercukupi kebutuhan unsur haranya dari pupuk anorganik yang diberikan, dan turi serta rumput benggala merupakan tanaman pakan yang toleran salinintas. Namun, jika salinitas tanah tinggi, maka dibutuhkan dosis lebih tinggi untuk menurunkan DHL, sehingga efek dosis 20 ton pukan/ha akan terlihat dan berbeda nyata dibanding dosis 10 ton pukan/ha. Menurut Purbajanti et al. (2010), untuk menurunkan salinitas tanah yang tinggi, diperlukan pemberian 20 ton pukan/ha yang ditambah 3 ton gypsum/ha, sehingga salinitas dapat turun hingga 50,1\%, DHL menurun dari $19,55 \mathrm{mS}$ menjadi $9,6 \mathrm{mS}$, dan serapan unsur hara oleh tanaman lebih optimal. Thohiron dan Prasetyo (2012) menyebutkan bahwa batas toleransi DHL untuk tanaman pada umumnya adalah $2 \mathrm{dS} / \mathrm{m}$. Salinitas tanah pada penelitian hanya $4,1 \mathrm{dS} / \mathrm{m}$, sehingga dapat diasumsikan pemberian pupuk kandang dengan dosis 10 ton/ha sudah mampu menurunkan salinitas tanah menjadi $2 \mathrm{dS} / \mathrm{m}$.

\section{Kadar Klorofil}

Hasil analisis ragam, menunjukkan bahwa sistem tanam serta dosis pupuk kandang tidak berpengaruh nyata terhadap kadar klorofil $b$, namun berpengaruh nyata $(p<0,05)$ terhadap kadar klorofil a dan klorofil total turi dan rumput benggala pada tanah salin. Hasil UJGD (Ilustrasi 1), menunjukkan bahwa kadar klorofil a dan klorofil total turi dan rumput benggala tanpa pupuk kandang nyata lebih rendah dibanding dengan pupuk kandang. Dosis 10 ton pukan/ha tidak berbeda nyata terhadap dosis 20 ton/ha, baik pada kadar klorofil a maupun klorofil total turi dan rumput benggala. Kadar klorofil a serta klorofil total turi dan rumput benggala dengan sistem tanam tumpangsari tidak berbeda nyata terhadap sistem tanam monokultur.

Garam - garam terlarut penyebab salinitas, mengandung ion - ion $\mathrm{Na}, \mathrm{Cl}, \mathrm{Al}, \mathrm{Fe}, \mathrm{Br}$ dan $\mathrm{Ca}$, yang meningkatkan $\mathrm{pH}$ serta menurunkan KTK tanah. Ion - ion tersebut juga bersifat toksik bagi tanaman. Tanah salin pada penelitian ini mempunyai $\mathrm{pH}$ mencapai 7,72 (agak alkalis), sedangkan KTK termasuk rendah, hanya 11,99 cmol $(+) \mathrm{kg}^{-1}$ dengan $\mathrm{Na}$ dapat ditukar (Nadd) hanya $0,37 \mathrm{cmol}(+) \mathrm{kg}^{-1}$. Kondisi tersebut secara tidak langsung menyebabkan unsur hara pembentuk dan katalis sintesis klorofil tidak 


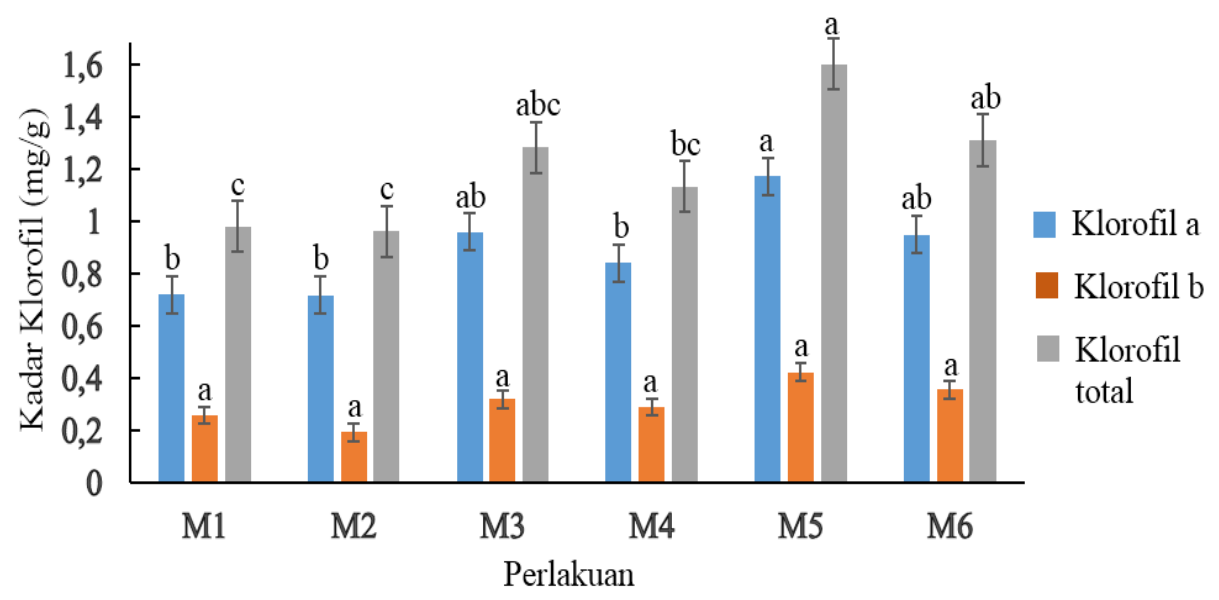

(a)

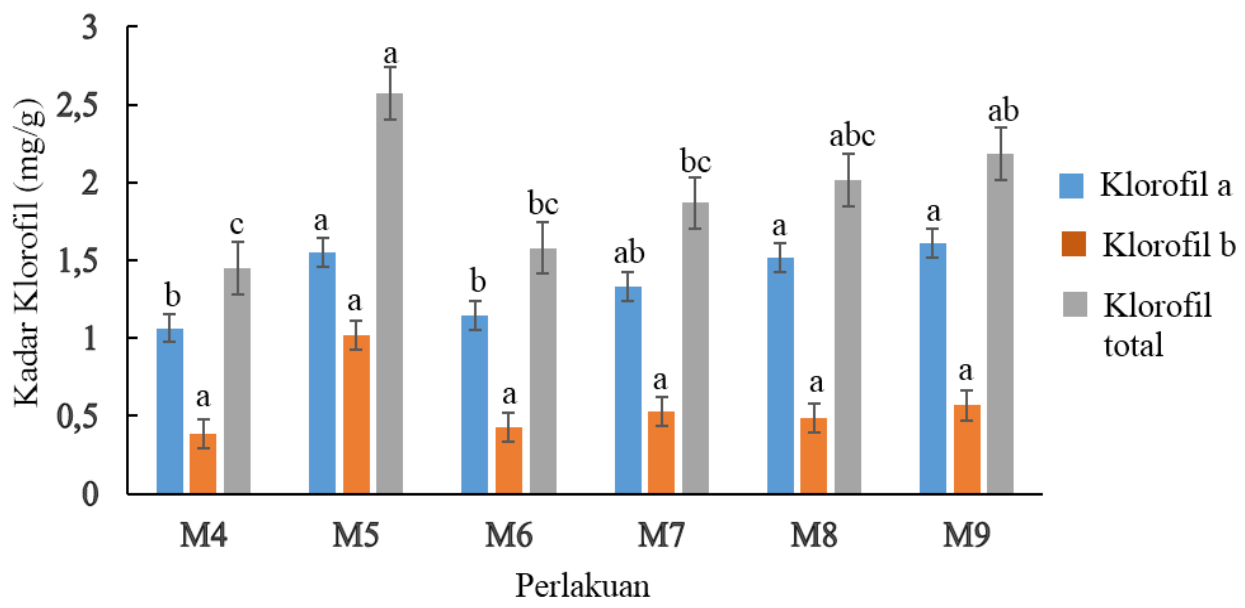

(b)

Ilustrasi 1. Kadar klorofil turi (a) dan rumput benggala (b) pada tanah salin dengan sistem tanam dan dosis pupuk kandang yang berbeda.

tersedia bagi tanaman. Subandi (2008), menyebutkan bahwa unsur hara tersebut meliputi $\mathrm{N}, \mathrm{Mg}, \mathrm{Fe}, \mathrm{Ma}, \mathrm{S}, \mathrm{Cu}, \mathrm{Zn}, \mathrm{CO}_{2}$, dan $\mathrm{O}_{2}$. Menurut Dwidjoseputro (1978), kekurangan salah satu unsur, terutama $\mathrm{N}, \mathrm{Mg}$, dan Fe sebagai unsur pensintesis klorofil, dapat mengakibatkan klorosis pada tanaman.

Pemberian pupuk kandang dimaksudkan untuk menurunkan $\mathrm{pH}$, meningkatkan KTK tanah, serta menurunkan toksisitas ion - ion beracun, sehingga air serta unsur hara yang berperan dalam sintesis klorofil tersedia bagi tanaman, dan kadar klorofil turi serta rumput benggala dapat meningkat. Menurut Cha-um et al. (2011), pupuk kandang mampu meningkatkan kapasitas tukar kation (KTK) tanah salin. Kation - kation penyebab toksisitas dapat diminimalisir, karena kompetisi antar ion positif dan ion negatif berada pada kompleks jerapan partikel koloid bahan organik pupuk kandang. Sutedjo (1995), menyatakan bahwa pupuk kandang mampu menurunkan $\mathrm{pH}$ tanah yang tinggi, sehingga meningkatkan ketersediaan air dan unsur hara untuk tanaman.

Kadar klorofil a serta klorofil total turi dan rumput benggala dengan sistem tanam tumpangsari tidak berbeda nyata terhadap sistem tanam monokultur. Hal ini dikarenakan turi masih 
berumur muda, dan rumput benggala tidak ternaungi oleh kanopi turi, sehingga distribusi intensitas cahaya merata ke seluruh tanaman. Kadar klorofil terendah pada penelitian ini terdapat pada klorofil $b$, hal ini juga menunjukkan bahwa tidak ada tanaman yang kekurangan cahaya (kondisi ternaungi). Menurut Subandi (2008), jika tanaman dalam kondisi ternanungi, kadar klorofil b akan lebih tinggi dibanding klorofil a dan klorofil total, sedangkan pada kondisi normal, kadar klorofil a akan lebih dominan $75 \%$ dari klorofil total. Menurut Lakitan (2010), kadar klorofil $b$ semakin tinggi ketika persebaran intensitas cahaya tidak merata (kondisi ternaungi), dikarenakan grana daun tanaman menghasilkan pigmen warna lebih banyak sebagai bentuk adaptasi daun untuk dapat menyerap cahaya lebih optimal.

\section{Produksi Bahan Kering}

Hasil UJGD (Tabel 2), menunjukkan bahwa produksi bahan kering turi dan rumput benggala tanpa pupuk kandang nyata lebih rendah $(\mathrm{p}<0,05)$ dibanding dengan pupuk kandang. Produksi bahan kering turi dan rumput benggala dengan dosis 10 ton pukan/ha tidak berbeda nyata terhadap dosis 20 ton pukan/ha. Produksi bahan kering turi dan rumput benggala dengan sistem tanam tumpangsari tidak berbeda nyata terhadap sistem tanam monokultur.
Produksi bahan kering turi dan rumput benggala tanpa pupuk kandang nyata lebih rendah dibanding dengan pupuk kandang. Hal ini dikarenakan pupuk kandang mampu menyediakan unsur hara makro dan unsur hara mikro, sehingga mampu meningkatkan pertumbuhan turi dan rumput benggala. Pertumbuhan optimal akan meningkatkan produksi bahan kering. Menurut Sitompul dan Guritno (1995), pertumbuhan tanaman yang optimal akan meningkatkan produksinya. Seseray et al. (2012), menyebutkan bahwa produksi bahan kering dipengaruhi produksi hijauan segar.

Bahan organik yang terdapat dalam pupuk kandang mampu memperbaiki sifat fisik tanah salin, dengan menggemburkan tanah yang seelumnya menjadi padat akibat akumulasi $\mathrm{NaCl}$ berlebih, sehingga mudah ditembus perakaran tanaman, dan serapan air dan unsur hara oleh tanaman dapat optimal. Serapan air dan unsur hara yang optimal akan meningkatkan pertumbuhan, dan secara tidak langsung meningkatkan produksi produksi bahan kering turi dan rumput benggala pada tanah salin. Menurut Sutedjo (2004), kandungan $\mathrm{NaCl}$ yang tinggi menyebabkan ruang pori berisi udara dalam agregat tanah menghilang dan tanah menjadi padat, sehingga serapan air dan unsur hara oleh tanaman terhambat. Sutedjo (1995) menyatakan bahwa bahan organik pupuk kandang mampu menggemburkan lapisan permukaan tanah (top soil), menetralkan $\mathrm{pH}$,

Tabel 2. Produksi bahan kering turi dan rumput benggala pada tanah salin dengan sistem tanam dan dosis pukan yang berbeda

\begin{tabular}{|c|c|c|}
\hline Perlakuan & Turi & Rumput \\
\hline & \multicolumn{2}{|c|}{-----------g/m²----------- } \\
\hline M1 (Turi) & $45,04^{\mathrm{c}}$ & - \\
\hline M2 (Turi +10 ton pukan/ha) & $215,00^{\mathrm{a}}$ & - \\
\hline M3 (Turi +20 ton pukan/ha) & $238,19^{\mathrm{a}}$ & - \\
\hline M4 (Tumpangsari) & $108,60^{\mathrm{b}}$ & $153,96^{\mathrm{c}}$ \\
\hline M5 (Tumpangsari +10 ton pukan/ha) & $208,64^{\mathrm{a}}$ & $612,71^{\mathrm{b}}$ \\
\hline M6 (Tumpangsari +20 ton pukan/ha) & $259,15^{\mathrm{a}}$ & $888,47^{\mathrm{a}}$ \\
\hline M7 (Rumput Benggala) & - & $249,10^{c}$ \\
\hline M8 (Rumput Benggala +10 ton pukan/ha) & - & $714,54^{\mathrm{ab}}$ \\
\hline M9 (Rumput Benggala +20 ton pukan/ha) & - & $817,62^{\mathrm{ab}}$ \\
\hline
\end{tabular}

Superskrip berbeda pada kolom yang sama menunjukkan perbedaan nyata $(p<0,05)$. 
Tabel 3. Nilai nisbah kesetaraan lahan

\begin{tabular}{ccccc}
\hline \hline Perlakuan & Hijauan & $\begin{array}{c}\text { Produksi bahan } \\
\text { kering sistem } \\
\text { tanam } \\
\text { tumpangsari }\end{array}$ & $\begin{array}{c}\text { Produksi bahan } \\
\text { kering sistem } \\
\text { tanam } \\
\text { monokultur }\end{array}$ & NKL \\
\hline \multirow{2}{*}{ Tanpa pukan } & Rumput Benggala & 153,96 & 249,10 & 3,02 \\
& $\begin{array}{c}\text { Turi } \\
\text { 10 ton pukan/ha }\end{array}$ & 108,61 & 45,04 & 1,82 \\
& Rumput Benggala & 612,71 & 714,55 & \\
& Turi & 208,64 & 215,01 & 2,17 \\
& Rumput Benggala & 888,48 & 817,62 & 2,17 \\
& Turi & 259,15 & 238,19 & \\
\hline
\end{tabular}

meningkatkan aktivitas mikroorganisme tanah, meningkatkan daya menahan air serta kesuburan tanah.

Nilai NKL (Tabel 3) tertinggi terdapat pada perlakuan tanpa pukan, dikarenakan tanaman masih dalam masa awal pertumbuhan, terutama turi. Sehingga produksi bahan keringnya masih rendah. Meskipun nilai NKL tertinggi, namun produksi bahan kering baik turi maupun rumput benggala pada perlakuan tanpa pukan tetap nyata lebih rendah dibanding dengan pukan. Produksi bahan kering rumput benggala tanpa pukan tidak terlalu rendah seperti turi, diduga karena kebutuhan $\mathrm{N}$ rumput benggala masih tercukupi dari pemberian pupuk urea. Namun, secara keseluruhan, Nilai NKL seluruh perlakuan lebih dari 1. Menurut Mahapatra (2011), nilai NKL lebih dari satu menunjukkan bahwa sistem tanam tumpangsari menghasilkan produksi lebih tinggi serta penggunaan lahan lebih efisien dibanding sistem tanam monokultur. Menurut Kusmiyati et al. (2016), nilai NKL antara turi dan rumput benggala pada tanah salin dengan pemberian mulsa jerami padi antara $1,4-1,7$, menunjukkan bahwa sistem tanam tumpangsari $40 \%-70 \%$ lebih efisien penggunaan lahannya dibanding sistem tanam monokultur.

\section{KESIMPULAN}

Aplikasi pupuk kandang dengan dosis 10 ton/ha mampu meningkatkan pertumbuhan, kadar klorofil a, kadar klorofil total, serta produksi bahan kering turi dan rumput benggala pada tanah dengan salinitas sedang (DHL 4,10 dS/m). Sistem tanam tumpangsari mampu meningkatkan efisisensi penggunaan lahan.

\section{DAFTAR PUSTAKA}

Abrol, I. P., J. S. V. Yadaf, and F. I. Massaud. 1988. Salt - Affected Soil and Their Management. Food And Agriculture Organization Of United Nations, Rome.

Balai Besar Penelitian dan Pengembangan Sumberdaya Lahan Pertanian. 2006. Karakteristik dan Pengelolaan Lahan Rawa. Bogor.

Cha-um, S., Y. Pokasombat, and C. Kirdmanee. 2011. Remediation of salt - affected soil by gypsum and farmyard manure - importance for the production of jasmine rice. Aust. J. Crop Sci. 5 (4): 458 - 465.

Dhanapackiam, S. and M. H. M. Ilyas. 2013. Effect of $\mathrm{NaCl}$ salinity on growth, nodulation and total nitroggen in Sesbania Grandiflora. Indian J. Sci. Technol. 3 (5) : $561-563$.

Dwidjoseputro. 1978. Pengantar Fisiologi Tumbuhan. Edisi Pertama. Gramedia, Jakarta.

Fuskhah, E., R. D. Soetrisno, S. Anwar, dan F. Kusmiyati. 2014. Kajian morfologi dan fisiologi ketahanan leguminosa pakan 
terhadap salinitas media tanam. Agromedia. $32(2): 45-53$.

Harjadi, S. S. M. M. dan S. Yahya. 1988. Fisiologi Stress Lingkungan. Bogor. Pusat Antar Universitas (PAU) Bioteknologi Institut Pertanian Bogor.

Hidayat dan Suwarno. 2012. Studi produksi dan kualitas rumput gajah (Pennisetum purpureum) varietas Thailand yang dipupuk dengan kombinasi organik-urea. Pastura. 2 (1) : 12 - 16 .

Kusmiyati, F., Sumarsono, Karno, and E. Pangestu. 2016. Influence of rice straw mulch on saline soil : forage production, feed quality and feed intake by sheep. J. Int. Soc. Southeast Asian Agric. Sci. 22 (1) : 42 -51 .

Lakitan, B. 2010. Dasar - Dasar Fisiologi Tumbuhan. Rajawali Press, Jakarta.

Mahapatra, S. C. 2011. Study of grass-legume intercropping system in terms of competition indices and monetary advantage index under acid laterilic soil of India. Am. J. Exp. Agr. 1 (1) : 1 - 6.

Prawiranata, W., S. Harran, dan P. Tjondronegoro. 1981. Dasar - Dasar Fisiologi Tumbuhan. Edisi Kedua. Institut Pertanian Bogor Press, Bogor.

Purbajanti, E. D., D. Soetrisno, E. Hanudin, dan S. P. S. Budhi. 2010. Respon rumput benggala (Panicum maximum L.) terhadap gypsum dan pupuk kandang di tanah salin. J. Agron. Indonesia. 38 (1) : 75 - 80 .

Salim, N., S. D. Anis, F. Dompas, dan W. B. Kaunang. 2016. Pengaruh pemupukan nitrogen dan tingkat naungan terhadap kandungan bahan kering, serat kasar, dan abu rumput Brachiaria humidicola. J. Zootek. 36 (1) 244 - 249.

Seseray, D. Y., E. W. Saragih dan Y. Katiop. 2012. Pertumbuhan dan produksi rumput gajah (Pennisetum purpureum) pada interval defoliasi yang berbeda. J. Ilmu Peternakan. 7 (1) : 31 - 36 .

Sitompul, S. M. dan B. Guritno. 1995. Analisis Pertumbuhan Tanaman. Gadjah Mada University Press, Yogyakarta.

Subandi, A. 2008. Pengantar Fisiologi Tumbuhan. Gramedia, Jakarta.

Susilawati, I., O. Indriani, H. Kemal, dan A. R. Tarmidi. 2011. Peningkatan berat akar, berat nodul efektif dan hasil hijauan legum dengan pemberian molibdenum dan inokulasi Rhizobium. J. Ilmu Ternak. 1 (10) : 39 - 44.

Sutedjo, M. M. 1995. Pupuk dan Cara Pemupukan. Edisi Kelima. Rineka Cipta, Jakarta.

Sutedjo, M. M. 2004. Analisis Tanah, Air, dan Jaringan Tanaman. Edisi Keempat. Rineka Cipta, Jakarta.

Tan, K. H. 1991. Dasar - Dasar Kimia Tanah. Edisi Pertama. Graha Ilmu, Yogyakarta. (Diterjemahkan oleh D. H. Goenadi).

Thohiron, M. dan H. Prasetyo. 2012. Pengelolaan lahan dan budidaya tanaman lahan terdampak lumpur marine Sidoarjo. J. Pembangunan dan Alam Lestari 1 : 19 - 27.

Yulipriyanto, H. 2010. Biologi Tanah dan Strategi Pengelolaannya. Edisi Pertama. Graha Ilmu, Yogyakarta. 